\title{
New Record of Arachnura melanura SIMON, 1867 (Araneae: Araneidae), from Japan, with the First Description of the Male
}

\author{
Akio TANikawA ${ }^{1)}$ \\ 谷川明男 ${ }^{1)}$ ：キオヒキグモの日本での新記録および雄の記載
}

\begin{abstract}
Arachnura melanura SIMON, 1867, is newly recorded from Japan. Its male is described for the first time. The previous record of the species from this country has been regarded as a misidentification.
\end{abstract}

Three species of the genus Arachnura, A. nipponica KISHIDA, A. melanura SIMON, 1867, and $A$. logio YAGINUMA, 1956, were recorded from Japan (YAGINUMA, 1957, 1968, 1970, 1977). Of these, $A$. nipponica KISHIDA was a nomen nudum (BRIGNOLI, 1983); and the specimen of $A$. melanura, "from IgA by Tsuiga", was reidentified as $A$. logio (YAGINUMA, 1986; YAGINUMA et al., 1990). Therefore, only one species, $A$. logio, remained in the Japanese fauna.

Among spiders newly collected from Iriomotejima Island, Okinawa Pref., Japan, I found some specimens identified with $A$. melanura, including several males. In my field work at the island from 1983 to 1990 , the total number of working days being 145 , only one species of Arachnura was obtained. Therefore, it was concluded that these females and males belong to the same species. In the present paper, I describe male of Arachnura melanura for the first time as well as female new to the Japanese fauna.

The abbreviations used in this paper are as follows: AME, anterior median eye; ALE, anterior lateral eye; PME, posterior median eye; PLE, posterior lateral eye; MOA, median ocular area.

Before going further, I wish to express my hearty thanks to Dr. Hirotsugu ONO, National Science Museum (Nat. Hist.), Tokyo, for his constant guidance and for correcting the manuscript of this paper, and to Dr. Takeo YAGINUMA, Osaka, for valuable informations and offering some copies of literature. My thanks are also due to Mr. Seiji MATSUMOTO, Kyorin University, Tokyo, and Norihisa TANAKA, Yokohama National University, Kanagawa, for their offering some important copies of literature.

1) Noba Senior High School, 1660, Noba-chô, Kônan-ku, Yokohama-shi, Kanagawa, 233 Japan 神奈川県立野庭高校 $干 233$ 神奈川県横浜市港南区野庭町 1660 


\section{A. TANIKAWA}

\section{Arachnura melanura SIMON, 1867 \\ [Japanese name: Ki-ohikigumo)}

(Figs. 1-6)

Arachnura melanura SIMON, 1867, Rev. Mag. Zool., 2(19): 17 [Type locality is in Malaysia. (SIMON, 1895)].

- SIMON, 1895, Hist. Nat. Araign., 1(4):776, fig. 847. —— ROEWER, 1942, Kat. Aran., 1:751. BONNET, 1955, Bibl. Aran., 2(1):372-CHRYSANTHUS, 1961, Nova Guinea, Zoology, (10):203, figs. 39-41, 68 .

Specimens examined. Iriomotejima Island, Yaeyama Islands, Okinawa Pref., Japan. A. TANIKAWA leg.: 3우우, 28-III-1985; 1 우, 29-III-1985; 1 ㅅ, , 30-III-1986; 1 시, 28-XII-1986; 1 우,

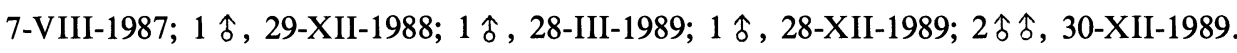

Description [based on the Japanese specimens; all the features of these female specimens exactly conform to the descriptions made by SIMON $(1867,1895)$, CHRYSANTHUS (1961) and UYEMURA (1976a,c), though no specimens from the other region were available]. Measurement.
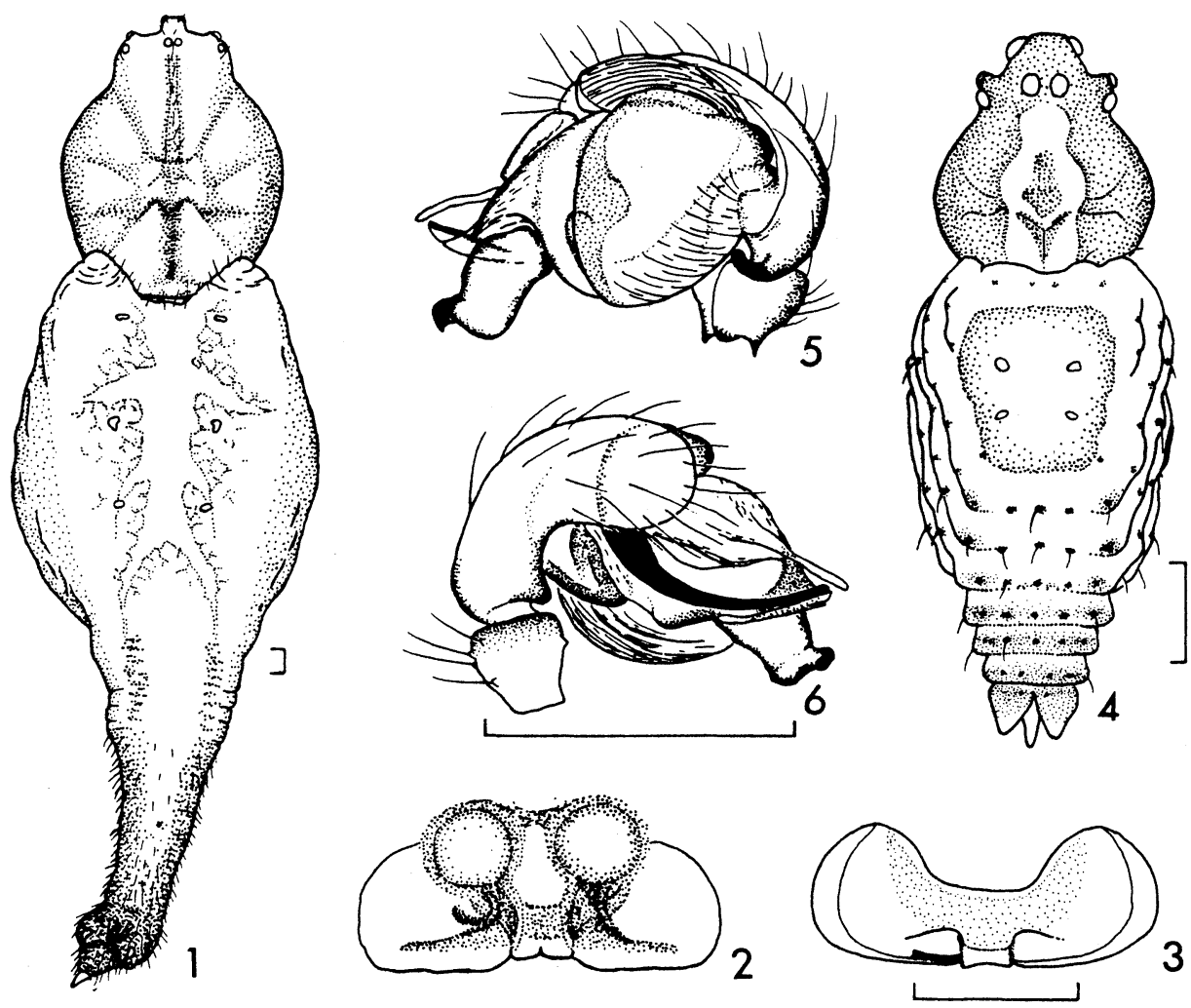

Figs. 1-6 Arachnura melanura SIMON, 1867.

1. Cephalothorax and abdomen of female, dorsal view.

2. Female genitalia, dorsal view. 3. Epigynum. 4. Cephalothorax and abdomen of male, dorsal view.

5. Left male palp, ventral view. 6. Same, dorsal view. (Scale: $0.25 \mathrm{~mm}$ ). 
Body length of $11.13-12.25 \mathrm{~mm}$, 요 $1.43-1.82 \mathrm{~mm}$; carapace length ㅇ $3.20-3.48 \mathrm{~mm}$, 令 $0.59-0.63 \mathrm{~mm}$; carapace width 우 $2.52-2.72 \mathrm{~mm}$, 요 $0.51-0.54 \mathrm{~mm}$; abdomen length 우 $8.20-9.30 \mathrm{~mm}$, 令 $0.93-1.21 \mathrm{~mm}$; abdomen width + $3.00-3.40 \mathrm{~mm}$, 今 $0.55-0.68 \mathrm{~mm}$. Length of legs of 1 ㅇ $1 \hat{\delta}$ as shown in Table 1 .

Female. Carapace longer than wide (length/width 1.27-1.33). Both rows of eyes recurved, AMEs lying on tubercle projected forward. MOA longer than wide (length/width 1.38-1.52), wider in front than behind (anterior width/posterior width 1.06-1.31). Clypeus nearly as wide as the diameter of AME (clypeus/AME 0.90-1.22). Chelicera with 4 promarginal and 3 retromarginal teeth. Labium wider than long (length/width $0.70-0.83$ ). Sternum slightly longer than wide (length/width 1.02-1.14). Abdomen longer than wide (length/width 2.55-2.87), anteriorly with a pair of prominent humps and caudally elongated (Fig. 1). Posterior part of the abdomen with three knobs, one at the end, two on the dorsal side; these knobs provided with white tips; some specimens (3우우 of 5 우우 examined) with two more tips without knobs on the ventral side. Female genitalia as shown in Figs. 2-3.

Male. Carapace slightly longer than wide (length/width 1.13-1.26), convex, anteriorly projected forward. AME the largest (ALE/AME 0.60-0.70, PME/AME 0.70-0.80, PLE/AME 0.70-0.80). MOA nearly as long as wide (length/width 0.92-1.02), wider in front than behind (anterior width/posterior width 1.44-1.50). Clypeus narrower than diameter of AME (clypeus/AME 0.60-0.80). Chelicera with many small teeth. Labium wider than long (length/width 0.60-0.64). Sternum nearly as long as wide (length/width 0.98-1.01). Male palp as shown in Figs. 5-6. Abdomen longer than wide (length/width 1.68-1.84), wrinkled, with many short bristles (Fig. 4). Posterior end of the abdomen with three dosal and two ventral projections.

Coloration and markings. Female. Carapace pale brown, with brown median line behind PMEs; thoracic region marginated with brown, rarely with brown band along cervical groove and radial furrows (Fig. 1). Chelicerae pale brown to brown. Maxillae pale brown to brown, inner margin yellow. Labium pale brown to brown, distally yellow. Sternum pale brown to brown, posterior part frequently darker. Legs pale brown to brown, tarsi and metatarsi darker. Tibia, patella and femur of second leg and metatarsus, tibia and patella of third leg dorsally dark brown. Dorsum of abdomen pale yellow, tail-like posterior part dark brown, frequently with a pair of dark brown band from median part to posterior end. Lateral sides and venter

Table 1 Measurement on leg segments of A. melanura SIMON, 1867 (in mm; 우/令).

\begin{tabular}{lllllll}
\hline Leg & Tarsus & Metatarsus & Tibia & Patella & Femur & Total \\
\hline I & $0.80 / 0.21$ & $1.96 / 0.23$ & $2.14 / 0.25$ & $1.44 / 0.22$ & $3.40 / 0.41$ & $9.74 / 1.32$ \\
II & $0.78 / 0.22$ & $1.86 / 0.21$ & $2.04 / 0.23$ & $1.44 / 0.20$ & $3.66 / 0.39$ & $9.78 / 1.25$ \\
III & $0.69 / 0.20$ & $1.18 / 0.16$ & $1.13 / 0.16$ & $1.13 / 0.16$ & $2.13 / 0.29$ & $6.26 / 0.97$ \\
IV & $0.74 / 0.23$ & $2.12 / 0.23$ & $2.08 / 0.25$ & $1.68 / 0.21$ & $3.08 / 0.41$ & $9.70 / 1.33$ \\
\hline
\end{tabular}




\section{A. TANIKAWA}

of abdomen pale brown to brown, lateral side darker than venter.

Male. Carapace dark brown, with wide yellow median band spotted with dark brown (Fig. 4). Chelicera brown. Maxillae brown, inner margin pale yellow. Labium brown, distally yellow. Sternum brown. Legs brown, femur, trochanter and coxa basally yellow. Dorsum of abdomen pale brown, with large brown patch in anterior part, and with many small brown spots on the bases of short bristles (Fig. 4). Venter of abdomen pale brown, with several grey spots.

Range. India (ROEWER, 1942), Malaysia (SIMON, 1895; BONNET, 1955), Indonesia (ROEWER, 1942; CHRYSANTHUS, 1961), Taiwan (YAGINUMA, 1957; UYEMURA, 1976a,c), Japan (the present paper).

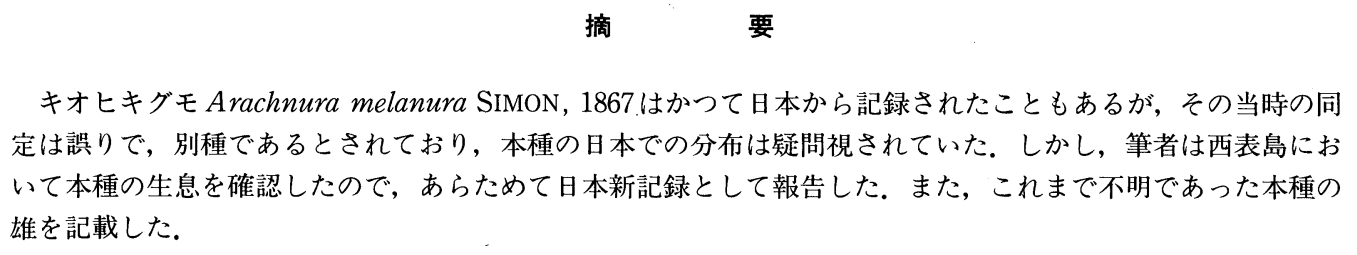
定は誤りで，別種であるとされており，本種の日本での分布は疑問視されていた。しかし，筆者は西表島にお いて本種の生息を確認したので，あらためて日本新記録として報告した。また，これまで不明であった本種の 雄を記載した。

\section{References}

BERLAND, L., 1932. Encyclopédie entomologique, 16. Les Arachnides. 485pp. Paris.

BONNET, P., 1955. Genus Arachnura. Bibliographia Araneorum, 2: 371-373.

BRIGNOLI, P.M., 1983. A Catalogue of the Araneae described between 1940 and 1981. 719pp. Manchester Univ. Press, Manchester.

BRAdLey, H.B., 1876. The Araneae of the Chevret-Expedition. I. Proc. Linn. Soc. N. S. Wales, 1: 137-150. CHRYSANTHUS, P., 1961. Spiders from South New Guinea IV. Nova Guinea, Zoology, (10): 195-214.

KOCH, L., 1871. Die Arachniden Australiens, Bd. I, pp.1-248. Nürnberg.

PlATNICK, N.I., 1989. Advances in Spider Taxonomy 1981-1987. 673pp. Manchester Univ. Press, Manchester.

ROEWER, C.F., 1942. Katalog der Araneae von 1758 bis 1940, Bd.1. 1040 pp. Natura, Bremen.

SIMON, E., 1867. Sur trois araignées nouvelles. Rev. Mag. Zool., 2(19): 15-24.

1895. Histoire Naturelle des Araignées. 1(4), pp.761-1084.

Strand, E., 1911. Araneae von den Aru- und Kei-Inseln. Abh. Senckenb. Naturf. Ges., 34: 127-199.

THORELL, T., 1890. Aracnidi di Nias e di Sumatra raccolti nel 1886 dal Sig. E. MOdigliANi. Ann. Mus. civ. Stor. nat. Genova, 30: 5-106. 1895. Descriptive Catalogue of the spiders of Burma. $406 \mathrm{pp}$. London.

TIKADER, B.K., 1970. Spider fauna of Sikkim. Rec. Zool. Surv. India, 64: 1-83.

UYemURA, T., 1976a. Notes on Arachnura species from Taiwan. Atypus, (66): 3-14. (In Japanese.) 1976b. Notes on Arachnura species from Borneo. Ibid., (67): 23-28. (In Japanese). 1976c. Specific names of Arachnura species from Taiwan. Ibid., (67): 29-32. (In Japanese.)

VINSON, A., 1863. Aranéides des îles de la Réunion, Maurice et Madagascar. 337 pp., 14 pls. Paris.

YAGINUMA, T., 1956. A new species of Arachnura (Araneae: Argiopidae) with an observation on its eggcocoons. Arachnol. News, (3): 1-4. 1957. Notes on Arachnura logio. Atypus. (12): 21-25. (In Japanese.) 
New Record of Arachnura melanura from Japan

1968. Spiders of Japan in Color (enl. rev. ed.). 197 pp. 56 pls. Hoikusha, Osaka. (In Japanese.) 1970. The spider fauna of Japan (revised in 1970). Bull. Natn. Sci. Mus., Tokyo, 13: 639-701. (In Japanese with English summary.)

1977. A list of Japanese spiders (revised in 1977). Acta Arachnol., 27(spec. no.): 367-406. (In Japanese with English synopsis.)

1986. Spiders of Japan in Color (n. ed.). 305 pp., 64 pls. Hoikusha, Osaka. (In Japanese.)

YAGINUMA, T., Y. HiRASHIMA \& C. OKUMA, 1990. Spiders, Etymology of their Scientific and Japanese Name. 287 pp. Kyushu Univ. Press, Fukuoka. (In Japanese)

YIN, C., Y. HU \& J. WANG, 1983. A new species of Genus Arachnura (Araneae: Araneidae) from China. J. Hunan Teachers Coll. (nat. Sci. Ed.) 1983: 1-5. 